Citation: Büyükbaş, Ş.M. \& Harmancı, Y., Effects Of Team-Member Exchange On Employee Performance, BMIJ, (2020), 8(3): 2617-2648, doi: http://dx.doi.org/10.15295/bmij.v8i3.1511

\title{
EFFECTS OF TEAM-MEMBER EXCHANGE ON EMPLOYEE PERFORMANCE
}

\author{
Şıh Mehmet BÜYÜKBAŞ 1 \\ Yasemin HARMANCI 2
}

\author{
Received Date (Başvuru Tarihi): \\ $18 / 05 / 2020$ \\ Accepted Date (Kabul Tarihi): \\ $2 / 07 / 2020$ \\ Published Date (Yayın Tarihi): \\ $25 / 09 / 2020$
}

In the article, the first author is in the role of the Corresponding Author.

\begin{abstract}
This study was carried out to determine the effects of team-member exchange on employee

Keywords:

Team-Member Exchange,

Task Performance,

Contextual Performance

JEL Codes:

M10

M12

M14

performance. In this context, task performance and contextual performance, the most widely accepted predictors of employee performance, were examined. The rationale behind choosing this subject was that relations between team members and the perception of these relations by employees were becoming more and more critical since the teamwork was much more engaged in professional life. Furthermore, it was thought that team-member exchange affects employee performance, which is one of the essential measures of work output. When investigating the subject, both theoretical and empirical studies were carried out. A questionnaire was conducted with a total of 403 employees working in six manufacturing firms in Kayseri, one of the most important industrial provinces of Turkey. Correlation analysis revealed significant correlations between team-member exchange and task performance. Moreover, there were also significant positive correlations between team-member exchange and contextual performance. Regression analysis revealed that teammember exchange had significant positive impacts on both task and contextual performance. In line with the findings of the present study, recommendations were provided to organization executives and researchers.
\end{abstract}

\section{TAKIM-ÜYE ETKILLEŞIMININ ÇALIŞANLARIN PERFORMANSLARI ÜZERINDEKII ETKİSI}

$\ddot{O Z Z}$

\section{Anahtar Kelimeler:}

Takım-Üye Etkileşimi,

Görev Performansl,

Bağlamsal Performans

\section{JEL Kodlar:}

M10

M12

M14
Bu çalışma takım-üye etkileşiminin çalışanlarm performanslarn üzerindeki etkisini tespit etmek amacıyla gerçekleştirilmiş̧tir. Çalışanların performansı açısından en yaygın olarak kabul görmüş olan görev performansı ve bağlamsal performans boyutlarn incelenmiştir. Araştırma konusunun tercih edilmesinin nedeni takım çalışmasının yaygınlaşmasının sonucunda takım üyeleri arasındaki iş ilişkileri ve takım üyelerinin bu ilişkiyi algılamasının önem kazanmasıdır. Ayrıca takım-üye etkileşiminin en önemli iş çıktılarından olan çalışan performansını etkilediği düşünülmektedir. Konuyu araştırmak için hem teorik hem de ampirik çalışmalar gerçekleştirilmiştir. Saha araştırması için Türkiye'nin önemli sanayi şehirlerinden Kayseri ilinde altı imalat işletmesinden 403 çalışana anket uygulaması gerçekleştirilmiştir. Korelasyon analizi sonuçlarına göre takım-üye etkileşimi ile görev performansı arasında pozitif ve anlamlı ilişki bulunmaktadır. Takım-üye etkileşimi ile bağlamsal performans arasında da pozitif ve anlaml ilişki bulunmaktadır. Regresyon analizi sonuçlarma göre takım-üye etkileşiminin görev performansinı ve bağlamsal performansı pozitif ve anlaml şekilde etkilediği tespit edilmiştir. Çalışmanın sonunda elde edilen bilgiler ve veriler doğrultusunda örgüt yöneticilerine ve araştırmacilara yönelik önerilere de yer verilmiştir.

\footnotetext{
1 Ph.D Student, Nevşehir Hacı Bektaş Veli University, Graduate School of Social Sciences, Department of Business Administration, sih_mehmet@hotmail.com https://orcid.org/0000-0003-2234-2223

2 Doctor Lecturer, Kayseri University, Faculty of Applied Sciences, Human Resources Management Departmant, ykaya@kayseri.edu.tr https://orcid.org/0000-0003-3800-0244
} 


\section{INTRODUCTION}

Expertise in organizations, present competitive conditions and ever-developing technology have all brought teamwork into prominence. Then such prominence has increased the significance of team-member exchange, a predictor for the quality and perception of the relationships between team members.

Today's business world forces employees to become more challenging for better performance of the tasks. Then, new concepts have been introduced into business life, and the practice of new methods has become evident (Seers et al., 2001: 3). Teammember exchange is a new concept and indicates the quality of the relations of an individual with the other team members. It is assumed that team-member exchange positively influenced teamwork and work performance. It is also assumed that if the team-member exchange level is low, then the level of appreciation and cooperation among team members will also be low. Thus such a case then will negatively influence work performance.

This study focused on the team-member exchange since it indicates the quality of the relations among team-members and was widely adapted and even became a pressing issue in business life. Since the performance is the most significant job outcome with direct contributions to the targets and outcomes of the teams and organizations, task performance and contextual performance of the employees were also included in this study. Organizations are trying to deal with two problems: how to improve the quality of team-member exchange and employee performance. Initially, theoretical information was provided about team-member exchange, task performance and contextual performance, then a survey and statistical analyses were performed to test the model hypothesis. With the model created, it was hypothesized that there were significant positive correlations between team-member exchange and task-contextual performance of the employees. It was also asserted that team-member exchange positively influenced employee performance. The present model is a new and principle model. An empirical study was conducted with this model to test the model hypotheses for manufacturing firms of Kayseri province. 


\section{LITERATURE REVIEW}

\subsection{Team-Member Exchange}

Employees of an organization are in either written or oral, either from close or further distance, either frequent or seldom have reciprocal dialogues or interactions. They are dependent on somewhere else in most of the tasks they performed. Such dialogue and mutual dependence bring about an exchange between the individual and the team. Klein and Kozlowski (2000) expressed such an exchange as: "How the exchange between the atoms constituted the molecular structure, the exchange between the individuals constitute performance of the team" (Klein and Kozlowski, 2000: 15). This exchange can also be expressed as a loop. Such a loop goes on with the team members, the team and the appropriate organizational environment (Ilgen et al., 2005: 519).

Behavioural structure and mechanisms play crucial roles in team performance. They can be expressed as coordination, cooperation and communication (Kozlowski and Bell, 2001: 37-38). Bonding tendency, indicating the feelings bonding team members to each other and the member to the team, also supports coordination, cooperation and communication. Such a bonding also increases the trust among team members and between the individual and the team (Ilgen et al., 2005: 527). Wech (2003) indicated that the quality of exchange between team members also indicated the efficiency of each individual (Tse and Dasborough, 2008: 195-196).

Team-member exchange measures the perception of the individuals about helping the others, sharing information and knowledge, feedback and recognition by the other members. In other words, the quality of team-member exchange indicates the efficiency of the relationships between the individuals and the team members (Seers, 1989: 119). Team-member exchange is a quite significant social support tool in the workplace (Shentu et al., 2013: 766). Team-member exchange also motivates employees in developing mutual relations (Tse and Dasborough, 2008: 210).

Seers (1989) introduced team-member exchange into the literature and wanted to express the mutual interactions of an individual with the other members of the team 
and conceived team-member exchange as a tool to assess such a mutuality. The concept of team-member exchange is used to assess exchange relations between team members about ideas, help, communication and support. Seers (1989) defined and assessed team-member exchange as the individual perception of the member about his/her relations with the rest of the team (Seers, 1989: 119).

In traditional approaches, the administration manages and coordinates the efforts of subordinates. On the other hand, in a team-oriented management approach, team members are allocated to greater authority and responsibility in decision making and self-administration. More significant roles and authorities of managers in traditional approach are reduced in a team-oriented management approach. Such a case offers all opportunities required to focus on establishing and sustaining highdegree cooperation among team members. Besides the other factors, the level of autonomy assigned to the team influence the average level of team-member exchange (Seers, 1989: 121).

According to Wech (2003), team-member exchange perception is strengthened when the job-related supports were provided to the team members. Such a strengthened team-member exchange then develops a team identity. In this way, team members also perceive how important they were for the team (Tse and Dasborough, 2008: 196).

The paper carried out by Ozkan and Borekci (2013) is the only study that appears in Turkey related to team-member exchange. In this study, the researchers looked for to reply to the questions of whether team-member exchange causes relative deprivation and how relative deprivations affect business outcomes. As a result of the research, it was found that team-member exchange has a compensatory effect on the weakness of leader-member exchange and complementary effect of leader-member exchange. The researchers pointed out that it is practically not possible to have a high degree of leader-member exchange with all members, and they revealed the importance of team-member exchange. They also found that the employee, who had low exchange level with the leader and other members, achieved positive business 
results thanks to the high positive organizational behaviour (Ozkan and Borekci, 2013: 114).

Team-member exchange is one of two social exchange formations in organizations with leader-member exchange (Lau, 2009). Team-member exchange and leader-member exchange are different concepts, and the differences between them are outlined below:

$\checkmark$ Team-member exchange reflects how members understand their exchange with other members as representatives of team identity rather than individuals. This is the opposite of the leader-member exchange, which is a mutual interpersonal dual form between the individual and her/his superior. Team-member exchange does not care about any differences that may occur as a consequence of reciprocal bilateral relations among various team members (Banks et al., 2014: 275).

$\checkmark$ The most apparent difference between leader-member exchange and teammember exchange is that team-member exchange is not dyadic. In other words, there is no mirror effect regarding the behaviour of the other person in the teammember exchange. Team-member exchange improves by the behaviour of the whole group and their consequences. The relationship between a central individual and a particular individual determines the quality of the leadermember exchange (Witt et al., 1999: 66).

$\checkmark$ Team-member exchange carries out a function that reveals the link among team members. However, leader-member exchange focuses on the reflection of the exchange between leaders and team members on team effectiveness and employee experience (Allison, 2016: 9-10).

$\checkmark$ Team-member exchange focuses on team dynamics and the content of the work, and its grounds on the fulfilment of roles related to this process. Leadermember exchange focuses on fulfilling the roles related to the leadership process in a managerial and supervisory way (Cogliser, 2013: 243). 
Team-member exchange focuses on reciprocity relationships between team member and all other team members. There are more than two individuals in the domain. However, in leader-member exchange, the mutual relationship between a leader and a team member is in the field of interest (Kidney, 2013: 64).

\subsection{Performance}

With the most straightforward expression, performance is defined as a targetoriented behaviour. Employee performance is expressed in activities to be performed by the employees to realize the targets of an organization and the outcomes to be reached (Rudman, 2003: 7). Measurable, multidimensional and dynamic behaviours of the individuals to reach the targets of the organization are defined as individual performance (Sonnentag and Frese, 2002: 18).

In recent studies, performance has been assessed in a multidimensional structure. Borman and Motowidlo (1993) also worked on this issue and expressed performance in two dimensions as of task performance and contextual performance. Researchers realized that job context was focused on while recruitment of the employees and tried to put forth the performance in a differentiated fashion indicating the supports provided to organizational efficiency (Motovidlo, 2003: 39-53). In the present study, employee performance was handled in two dimensions as it was widely recognized in literature: task performance and contextual performance.

\subsubsection{Task Performance}

The task is defined as the activities to be performed by an employee in a specific rationale and sequence for the performance of the job assigned to him. For instance, for staff responsible for tea-making, brewing and service of tea are separate tasks (Timur and Kılıç, 2005: 22). Task performance and competence are mentioned in almost all performance definitions. Task performance, in essence, expresses technical competence (Schmitt et al., 2003: 80). 
There are two dimensions of task performance. The first one is the activities in the process of conversion of raw materials into the final product or services. Sale and advertising activities in stores, production activities, teaching in a school or tellership in a bank are all this kind of task performance. The second dimension of task performance includes distribution, supply, technical maintenance and similar activities to realize relevant product and services. This dimension also includes activities like planning, organization, administration, personnel affairs, etc. which are required for the efficient and productive performance of organizational activities. In brief, task performance covers the activities for the execution and maintenance of technical processes of an organization (Motovidlo, Borman and Schmit, 1997: 75).

Besides the performance of the things required by the task, task habits have contributions to morale and motivation. Individuals know better about how to react in different cases. For instance, sale representatives should know about how to treat, cope with and empathize with nervous customers and they should be able to apply this knowledge (Motovidlo, Borman and Schmit, 1997: 81). Additionally, cultural intelligence and general self-efficacy predicted task performance (Sahin and Gurbuz, 2012: 125).

\subsubsection{Contextual Performance}

Contextual performance can be defined as behavioural patterns supporting psychological and social context and contributing to the efficiency of the organization as well as job-related activities. Contextual activities are not the official parts of the job and include voluntary cooperative activities to reach the targets of the organization (Borman and Motovidlo, 1997: 100). Contextual performance, in essence, briefly is to ease the jobs of the employees and commitment to the job (Van Scotter and Motovidlo, 1996: 525).

Contextual performance expresses the behaviours supporting the job and also influencing compulsory technical activities rather than the technical aspect of the job. Thus, it includes voluntary and keenly performed activities not included in the fundamental structure of the job (Schmitt et al., 2003: 81). Contextual performance is 
wholesome of psychological, social and organizational behaviours with great supports to the job (Motovidlo, 2003: 44).

Contextual performance is a concept expressing the better performance of the job by the employees to realize organizational targets. Cooperation with the other employees, taking the initiative in solving the problems and voluntary aids to other employees can be included in the contextual performance. In this way, organizations take advantage over the competitors (Han, Chiang and Chiang, 2013: 282).

Borman and Motowidlo (1993), outstanding contextual performance in the following five dimensions in "Expanding the Criterion Domain to Include Elements of Contextual Performance. In Personnel selection in organizations" (Motovidlo, 2003: 45): i) To voluntarily carry out non-mandatory activities to realize the work. ii) Excessive desire and effort to achieve or complete a business when necessary. iii) To assist and cooperate with other employees. iv) To comply with organizational rules and procedures, even if it is difficult and laborious. v) To approve, support and defend the objectives of the organization.

\subsubsection{Task Performance Versus Contextual Performance}

There are three main differences between task performance and contextual performance (Borman and Motowidlo, 1997: 102-103):

$\checkmark$ Task performance varies pursuant job, but contextual performance is similar across all jobs.

$\checkmark$ Defining task performance and setting its rules are possible than contextual performance.

$\checkmark$ Task performance concerns skills, and contextual performance concerns personality and motivation.

Task performance focuses more on the performance of employees in line with their job descriptions. However, the contextual performance focuses on behaviours that employees exhibit outside their job descriptions and more contribute to the integrity of the organization (Unlu and Yurur, 2011: 183). Borman and Motowidlo 
(1997) propose that if the task according to personality criteria and contextual performance is measured in personality measurements, personnel selection activities will be more successful (Borman and Motowidlo, 1997: 103).

Task performance consists of fulfilling a job. Contextual performance is more concerned with voluntary behaviours that support an organization's success. The success of an organization depends on the power of employees to innovate realization and on their performance and behaviour that will contribute to the organization. This contribution can be provided by a quality leader-member exchange. The commitment, support, and helpful behaviour, etc. need to show behaviour to obtain this contribution (Akdogan, Cingoz and Mirap, 2009: 380-381).

Contextual performance does not contribute through the technical affairs of the organization. However, it denotes to organizational, social and psychological activities, including more comprehensive and technical activities necessary for the fulfilment of the technical function. Individuals are supported and helped by these activities. The contribution is realized to the organization's goals by conducting the business successfully. Even activities that are not a formal part of the job are carried out voluntarily and enthusiastically. Employees with high contextual performance are more motivated for their jobs, maintain good relationships with other employees, do their jobs more effectively, comply with organizational rules and procedures, and conduct their jobs more internally and voluntarily. In summary, the main difference between task performance and contextual performance is that task performance directly contributes to the technical content of the production or service. In contrast, contextual performance positively affects the psychological and social environment, creating the necessary conditions for the technical content of the work to be done more effectively and productivity (Motovidlo, Borman and Schmit, 1997: 75-76).

Personality characteristics affect the behaviour of individuals. In this context, conscience, extraversion and agreeableness personality traits in a team are predictors of contextual performance. There is a stronger relationship between reliability, collaboration and job orientation and contextual performance than the relationship between these variables and task performance (Tuna, 2014: 24). Accordingly, it can be 
uttered that task performance and contextual performance are also different in terms of being affected by personality.

Organizations can evaluate task performance and contextual performance with different weighted average values during performance evaluation. For example, a firm can give contextual performance twice the weighted average value of task performance (Murphy and Shiarella, 1997: 832).

In a study by Polatc1 (2014), it has been determined that psychological capital positively and significantly affect task performance, contextual performance and total performance. When the dimensions of psychological capital are analyzed separately, it is determined that hope and resilience have a positive and significant effect on total performance. The effect of optimism and self-efficacy on total performance has not been proven. It has been determined that hope and resilience affect task performance positively and significantly, and optimism and self-efficacy do not have a significant effect on task performance. It was found that contextual performance affects only the resilience dimension positively and significantly, and the dimensions of hope, selfefficacy and optimism had no significant effect on contextual performance (Polatc1, 2014: 120-121). Accordingly, it can be stated that there is a difference between task performance and contextual performance in terms of psychological capital.

Aktas and Simsek (2014) carried out a study evaluating task performance and contextual performance in terms of organizational silence and organizational culture. In this study, contextual performance will increase as the pro-social silence increases, and the organization becomes less market-oriented. Market culture reduces contextual performance, but contextual performance does not increase when market culture is designed as desired in an organization. If evaluated in this context, market culture reduces contextual performance, but contextual performance does not increase when market culture is designed as desired in an organization. As a result, as the pro-social silence and adhocracy culture increases, performance increases, and as the culture of acquiescent silence, market and hierarchy culture increases, performance decreases. 
If organizational culture is as desired, the determining role of culture and acquiescent silence on performance disappears. In line with the increasing pro-social silence scores and increasing market-oriented culture perception, an increase in the contextual performance of the employees was also detected. It was determined that task performance increased with pro-social silence, perceived adhocracy and hierarchy culture in the organization. Pro-social silence, perceived adhocracy and hierarchy culture have a positive and significant effect on task performance (Aktaş and Şimşek, 2014: 46-48).

\subsection{Team-Member Exchange and Performance Relations}

The concept of team-member exchange has emerged from the relations among team members. The concept has become the subject matter of recent researches and mostly the relations of the concept with the performance, which is the most significant job outcome, were investigated.

Seers (1989) indicated for the first time that team-member exchange in organizations could reliably be measured and the concept was related to job outcomes or performance. Seers (1989) also indicated that team-member exchange reflected the role-making process of the individuals within the teams and pointed out the significance of role-making, which was mostly neglected in previous studies. Seers (1989) conducted a survey study with automotive industry workers and reported separate significant relations of team-member exchange with job satisfaction, job performance and leader-member exchange. It was proved in that study that job performance was more remarkable at high team-member exchange levels. Significant positive correlations were reported between team meeting efficiency and teammember exchange and between team cohesiveness and team-member exchange (Seers, 1989: 127-134). Kamdar and Van Dyne (2007) conducted a study with engineers and their team leaders and reported weak positive correlations between team-member exchange and task performance (Kamdar and Van Dyne, 2007: 1292). Suskind, Behfar and Borcgrevink (2006) indicated that team-member exchange had significant positive effects on individual performance (Suskind, Behfar and Borcgrevink, 2006: 130-131). All these literature revealed that knowledge had more significant supports to 
individual performance than the effort and such literature also indicated that organizations adapted performance and customer-oriented processes instead of process-oriented businesses.

Seers et al. (2001) handled team-member exchange in two aspects: contributions -provided to other members and receipts- supplied from the other members. Researchers gathered data from mid-level executives of the insurance sector and indicated that contributions had positive effects on both horizontal and vertical activities of the executives. They also indicated that receipts did not have significant effects on horizontal and vertical activities of the executives (Seers et al., 2001:12). Alge, Wiethoff and Howard (2003) conducted analyses on data gathered from undergraduate students and reported significant positive correlations between teammember exchange and decision-making performance in tasks requiring high commitment levels. Researchers were not able to prove such a correlation for the tasks requiring low commitment levels (Alge, Wiethoff and Klein, 2003: 33). Liu, Keller and Shih (2011) conducted an empirical study with the R\&D project teams and identified the moderator role of team-member exchange differentiation in the positive effects of team-member exchange on team performance. Effects of team-member exchange on performance varied inversely with team-member exchange differentiation. That study was prominent with the assessment of outcomes at the team level (Liu, Keller and Shih, 2011: 281-284). Liu, Loi and Lam (2011) conducted a study with the employees of automobile dealers and indicated the mediating role of team-member exchange in relationships between organizational identity and task performance, in other words, they indicated that such a relationship was more robust when the team-member exchange level was high. However, they were not able to provide the moderator role of team-member exchange in this relationship. It was understood from here that employees were not affected in their job relations when they have a full organizational identity and focused directly on their tasks. However, the case is different when the contextual performance was considered instead of task performance. Researchers indicated moderator role of team-member exchange in relationships between organizational identity and contextual performance; in other words, they proved that such a relationship was more robust at high team-member exchange levels. In this 
way, it was concluded that organizational efforts to develop interactions between the employees had positive contributions to contextual performance (Liu, Loi and Lam, 2011: 3195-3198). Pollack and Rutherford (2008) gathered data from network groups and indicated that team-member exchange positively influenced referrals which is an important performance criterion in network groups. In other words, high teammember exchange levels encouraged team members for more significant referrals (Pollack and Rutherford, 2008: 1). Pollack et al. (2016) took several referrals taken and given by network group staff for their potential customers to improve their performance as performance criteria and reported that team-member exchange did not have direct impacts on some referrals they took and gave. However, they indicated that with the mediating role of emotional commitment, team-member exchange positively influenced the given and taken many referrals (Pollack et al., 2016: 31). Tse and Lawrence (2010) conducted an empirical study for the banking sector. They proved that there was a negative relationship between leader-member exchange differentiation and team performance and team-member exchange had an intermediary role in this negative relation and eliminated such a negative relationship (Tse and Lawrence, 2010: 11). Liden, Wayne and Sparrowe (2000) carried out a study with service organizations and put forth the mediating role of personnel strengthening in relationships between team-member exchange and job performance. Researchers also indicated that team-member exchange had significant positive effects on job performance. Because of performance-improving effects of team-member exchange, Liden, Wayne and Sparrowe (2000) also recommended further comprehensive studies focusing primarily on team-member exchange at both teams and individual levels and the relations of team-member exchange with job performance and personnel strengthening (Liden, Wayne and Sparrowe, 2000: 412-414).

Employees in teams are in continuous exchange with the other employees. Such an exchange goes on with the colleagues in multiple fashions. Roles of the individuals also have an important place in such exchange (Seers, 1989: 132). Relevant literature review and outcomes of the previous studies revealed that there was a positive correlation between the team-member exchange and employee performance and teammember exchange improved performance. It was also inferred from the previous 
studies that team-member exchange had a mediating or moderator role in relations of performance with some other variables in organizations.

\section{AN EMPIRICAL STUDY TO DETERMINE THE EFFECTS OF TEAM-} MEMBER EXCHANGE ON EMPLOYEE PERFORMANCE

\subsection{Significance and Objective of The Study}

Individuals of organizations are in continuous exchange with the team in which they take part. Performance is expressed as the goal-attaining and implementation level of the tasks by the employees by the pre-specified criteria. Performance is a quite significant issue for the organizations to reach their targets efficiently and productively. There are several indicators for the performance in organizations, and team-member exchange is thought to influence employee performance. In this study, effects of team-member exchange on "task performance" (focusing on the horizontal exchange of team members with the team and indicating the member perceptions about support, cooperation and communication within the team and being related to primary components and technical aspects of the job) and "contextual performance" (focusing on individual competencies apart from primary components and including behaviours with positive impacts in reaching targets of the organizations) were investigated.

In virtue of the significance of the current research topic, the primary objectives were set as to provide contributions to present literature, encourage researches for new studies about team-member exchange; to provide recommendations to executives and human resources managers of the organizations; to provide a different perspective for relationships among the individuals through better comprehension of team-member exchange; with the model to be created, to determine the effects of team-member exchange on employee performance; to put forth differences in team-member exchange based on the relationships between team-member exchange and employee performance and based on demographic factors. 


\subsection{Research Constraints}

Potential constraints restricting the significance level of research outcomes can be itemized as follows: i) convenience sampling was used, and questionnaires were applied to participants who accepted to participate into the study from the organizations whose executives accepted to apply questionnaires in their organizations. ii) Respond was not received from some questionnaires, some respondents were not able to be assessed, or routine and negative response were provided to some questions as a reaction. iii) Some participants had hesitated or short responds to questions since they hesitated to create a negative attitude or worried about the wrong response. iv) Some employees hesitated about whether or not they were included in the team or included in which team.

\subsection{Research Model and Hypothesis}

Along the with objectives of the study, a model was created, and team-member exchange was considered as an independent variable predicting employee performance, task performance and contextual performance were considered as dependent variables. The relations of team-member exchange with task performance and contextual performance were also included in the research model.

The research model developed to indicate the relations of team-member exchange with task and contextual performance is presented in Figure 1.

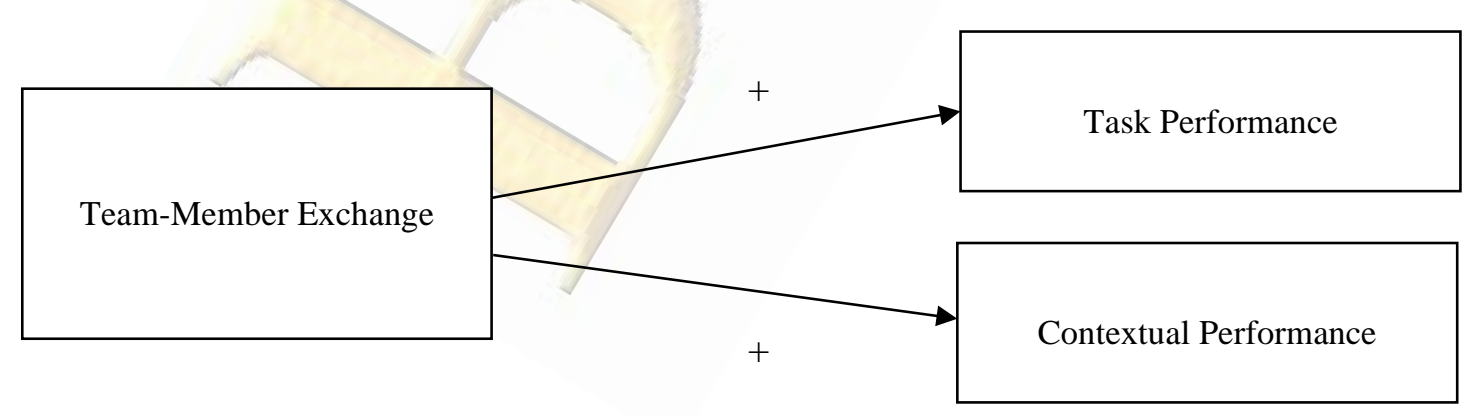

Figure 1. Research Model 
Along with the model developed, the following hypotheses were created:

Hypothesis 1: There is a significant positive correlation between team-member exchange and task performance of the employees.

Hypothesis 2: There is a significant positive correlation between team-member exchange and contextual performance of the employees.

Hypothesis 3: Team-member exchange has positive impacts on the task performance of the employees.

Hypothesis 4: Team-member exchange has positive impacts on the contextual performance of the employees.

\subsection{Research Methodology}

\subsubsection{Research Universe and Sample}

Research universe was constituted by manufacturing firms operating in Kayseri Organized Industrial Zone and surroundings of Kayseri, which is among the significant industrial provinces of Turkey. According to the most recent data, 52.000 employees are working in Kayseri Organized Industrial Zone (Kayseri Province 2015 Yearly Environment and Situation Report, 2016: 79). Based on this universe size, the ideal sample should include 382 individuals at 55 error and 95\% confidence level (http://fluidsurveys.com/university/survey-sample-size-calculator/). Convenience sampling method was used to select sample size, and the final sample size was identified as 403 individuals. Although the ideal sample size was 382 individuals, questionnaires were performed with 403 individuals determined by convenience sampling method. Questionnaires were applied to 6 manufacturing firms. Of 983 questionnaire forms, respond was received from 437 of them, 34 forms were not assessed since they were not found to be suitable for assessments. Thus a total of 403 forms were assessed. Based on distributed questionnaire forms, 44\% participation and $41 \%$ assessment were achieved.

The data were collected in March and April 2017. So, no ethics committee permit is required. 


\subsubsection{Data Gathering}

Questionnaires were used to gather data. The questionnaire forms were composed of 4 sections. Scales about the variables were provided in the first 3 sections. The opinions about the statements of the scales were scored in a 5-point Likert scale with 1: Totally disagree, 2: Disagree, 3: No idea, 4: Agree and 5: Totally agree.

In the first section of the questionnaire, a scale with 13 statements about the team-member exchange developed by Seers et al. (2001) was used. For scale reliability, Cronbach Alpha $(\alpha)$ value was identified as 0,77 for contributions provided to the other members and 0,86 for receipts from the other members (Seers et al., 2001: 21). In the second section of the questionnaire, a scale with 21 statements developed by Williams and Anderson (1991) was used to measure task performance $(a=0,91)$ (Williams and Anderson, 1991: 610). Since the 6, 7, 17, 18 and 19th statements of the scale were negative, their codes were entered in reverse order. In the third section of the questionnaire, a scale with 16 statements developed by Borman and Motowidlo (1993) was used to measure contextual performance (Motovidlo and Van Scotter, 1994: 477) $(a=0,95)$. In the last section of the questionnaire, questions were asked about demographic characteristics of the participants. Statistical analysis software was used for data analysis.

\subsection{Results}

The results obtained by using the appropriate analysis methods and analyses were itemized below.

\subsubsection{Scale Reliability}

Cronbach Alpha value was identified as 0,914 for team-member exchange scale, 0,925 for task performance and 0,938 for contextual performance (Table 1). Based on these Cronbach Alpha values, scales were found to be "highly reliable" (Nakip, 2013: 205). 
Table 1. Cronbach Alpha Values for the Variables

\begin{tabular}{|c|c|}
\hline Variables & Cronbach Alpha \\
\hline Team-Member Exchange & 0,914 \\
\hline Task Performance & 0,925 \\
\hline Contextual Performance & 0,938 \\
\hline
\end{tabular}

\subsubsection{Participant Demographic Characteristics}

About the age of participants, they were mostly (42,7\%) between the ages of 3645 years, 36,2\% were between 26-35 years old, 9,9\% were between $46-55$ years old, 9,7\% were between 18-25 years old, and the least (1,5\%) was over 56 years old.

Table 2. Demographic Characteristics

\begin{tabular}{|l|l|l|}
\hline \multicolumn{1}{|c|}{ Age } & \multicolumn{1}{c|}{ Frequency } & \multicolumn{1}{c|}{ Percent } \\
\hline $18-25$ & 39 & 9,7 \\
\hline $26-35$ & 146 & 36,2 \\
\hline $36-45$ & 172 & 42,7 \\
\hline $46-55$ & 40 & 9,9 \\
\hline 56 and over & 6 & 1,5 \\
\hline Total Gender & $\mathbf{4 0 3}$ & $\mathbf{1 0 0}$ \\
\hline \multicolumn{1}{|c|}{ Frequency } & Percent \\
\hline Female Education Level & 43 & 10,7 \\
\hline Male & 360 & 89,3 \\
\hline Total & $\mathbf{4 0 3}$ & $\mathbf{1 0 0}$ \\
\hline & 160 & \multicolumn{1}{c|}{ Percent } \\
\hline Primary School Education & 184 & 39,7 \\
\hline High School Education & 17 & 45,7 \\
\hline Vocational School Education & 37 & 4,2 \\
\hline Undergraduate Education & 5 & 9,2 \\
\hline Graduate Education & $\mathbf{4 0 3}$ & 1,2 \\
\hline Total Marital Status & \multicolumn{1}{|c|}{ Frequency } & \multicolumn{1}{c|}{ Percent } \\
\hline & 326 & 80,9 \\
\hline Married & 70 & 17,4 \\
\hline Single & 7 & 1,7 \\
\hline Other & $\mathbf{4 0 3}$ & $\mathbf{1 0 0}$ \\
\hline Total & & \\
\hline
\end{tabular}


Of the participants, $10,7 \%$ were female, and $89,3 \%$ were male. Concerning educational levels of the participants, $45,7 \%$ had a high-school education, 39,7\% had primary school education, 9,2\% had undergraduate education, 4,2\% had vocational school education, and only 1,2\% had graduate-level education. About the marital status of the participants, $80,9 \%$ were married, $17,4 \%$ were single, and $1,2 \%$ were other. Results are provided in Table 2.

\subsubsection{Correlation and Regression Analysis}

Correlation analysis was performed to test the first two hypotheses of the research. Results are provided in Table 3.

Table 3. Mean and Standard Deviations for the Variables and Correlation Coefficients Between the Variables

\begin{tabular}{|c|c|c|c|c|c|}
\hline Variables & Mean & $\begin{array}{c}\text { Standard } \\
\text { Deviation }\end{array}$ & $\mathbf{1}$ & $\mathbf{2}$ & $\mathbf{3}$ \\
\hline $\begin{array}{c}\text { 1. Team-Member } \\
\text { Exchange }\end{array}$ & 3,6368 & 10,11487 & 1 & & \\
\cline { 4 - 6 } 2. Task Performance & 4,0045 & 14,89235 & $0,502^{* *}$ & 1 & \\
\cline { 4 - 6 } & & & 0,000 & & 1 \\
\hline \multirow{2}{*}{ 3. Contextual Performance } & 3,9339 & 11,68552 & $0,522^{* *}$ & $0,702^{* *}$ & 1 \\
\cline { 4 - 6 } & & & 0,000 & 0,000 & \\
\hline
\end{tabular}

${ }^{* *} \mathrm{p}<0,01$

Correlation analysis revealed that:

- There were significant positive correlations between team-member exchange and task performance of the employees $(\mathrm{r}=0,502, \mathrm{p}<0,01)$. Then, Hypothesis 1 created with the developed model was accepted. According to correlation coefficient rating criteria (Nakip, 2013: 427), this correlation was rated as "quite weak".

- There were significant positive correlations also between team-member exchange and contextual performance of the employees $(\mathrm{r}=0,522, \mathrm{p}<0,01)$. Then, Hypothesis 2 created with the developed model was accepted. According 
to correlation coefficient rating criteria (Nakip, 2013: 427), this correlation was rated as "relatively strong".

Pair-wise regression analysis (linear) was performed to test the third and fourth hypotheses of the research. Results are provided in Table 4-5.

Table 4. Regression Analysis Indicating the Effects of Team-Member Exchange on Task Performance

\begin{tabular}{|c|c|c|c|c|c|c|c|c|}
\hline \multirow{2}{*}{$\begin{array}{l}\text { Model } 1 \\
\text { Predictors }\end{array}$} & \multicolumn{2}{|c|}{$\begin{array}{l}\text { Unstandardized } \\
\text { Coefficients }\end{array}$} & \multirow[t]{2}{*}{\begin{tabular}{|c|} 
Standardized \\
Coefficients
\end{tabular}} & & & \multicolumn{2}{|c|}{$\begin{array}{l}\text { Collinearity } \\
\text { Statistics }\end{array}$} & \multirow{2}{*}{$\mathrm{CI}$} \\
\hline & B & \begin{tabular}{|c|} 
Standard \\
Error
\end{tabular} & & & & Tolerance & VIF & \\
\hline Constant & 49,132 & 3,074 & & 15,985 & $0,000^{* *}$ & & & 1,000 \\
\hline Team-Member Exchange & 0,740 & 0,064 & $\underline{0,502}$ & 11,632 & $0,000^{* *}$ & 0,322 & 3,543 & 12,583 \\
\hline $\mathrm{R}$ & \multicolumn{8}{|l|}{0,502} \\
\hline $\mathrm{R}^{2}$ & \multicolumn{8}{|l|}{0,252} \\
\hline Adjusted $\mathrm{R}^{2}$ & \multicolumn{8}{|l|}{0,250} \\
\hline Estimated Standard Error & \multicolumn{8}{|c|}{12,89355} \\
\hline $\mathrm{F}_{(1-401)}$ & \multicolumn{8}{|c|}{135,299} \\
\hline Sig. & \multicolumn{8}{|c|}{$0,000^{* *}$} \\
\hline Durbin-Watson & \multicolumn{8}{|l|}{1,918} \\
\hline
\end{tabular}

Dependent Variable: Task Performance ** $\mathrm{p}<0,01$ **

As can be inferred from the regression tables indicating the effects of teammember exchange on task performance, the regression model 1 created were significant. $\left(\mathrm{R}^{2}=0,252 ; \mathrm{F}_{(1-401)}=135,299 ; \mathrm{p}<0,01\right)$. According to pair-wise (linear) regression analysis, it was observed that team-member exchange levels of the participants positively influenced their task performance $(\beta=0,502 ; \mathrm{p}<0,01)$.

VIF (Variance Inflation Factors) value was calculated as 3,543 in the regression model. The highest value in the literature is accepted to be 10 (Gujarati and Porter, 2009). This value is well below 10 value. Again, the tolerance value is 0.322 ; is much higher than the lowest value $(0,100)$ (Hair et al., 1992). It means that there is not a multicollinearity problem in the regression model. Besides, it is seen that the CI (condition index) value is 12,583 . This is much lower than the top value of 30 . Also, the Durbin- 
Watson coefficient is 1,918. So it is below the value of 2 that should not exceed (Gujarati and Porter, 2009). Therefore, there is no autocorrelation problem in the regression model.

Team-member exchange was able to explain $25 \%$ of the variation in task performance (adjusted $R^{2}=0,250$ ). Then, Hypothesis 3 was accepted.

Table 5. Regression Analysis Indicating the Effects of Team-Member Exchange on Contextual Performance

\begin{tabular}{|c|c|c|c|c|c|c|c|c|}
\hline \multirow{2}{*}{$\begin{array}{l}\text { Model } 2 \\
\text { Predictors }\end{array}$} & \multicolumn{2}{|c|}{$\begin{array}{c}\text { Unstandardized } \\
\text { Coefficients }\end{array}$} & \multirow[t]{2}{*}{$\begin{array}{c}\text { Standardized } \\
\text { Coefficients }\end{array}$} & & \multirow{2}{*}{ Sig. } & \multicolumn{2}{|c|}{$\begin{array}{l}\text { Collinearity } \\
\text { Statistics }\end{array}$} & \multirow{2}{*}{$\mathrm{CI}$} \\
\hline & B & $\begin{array}{c}\text { Standard } \\
\text { Error }\end{array}$ & & & & Tolerance & VIF & \\
\hline Constant & 34,455 & 2,380 & & 14,479 & $0,000^{* *}$ & 7 & & 1,000 \\
\hline Team-Member Exchange & 0,603 & 0,049 & $\underline{0,522}$ & 12,241 & $0,000^{* *}$ & 0,281 & 3,294 & 11,137 \\
\hline $\mathrm{R}$ & 0,522 & & & & & & & \\
\hline $\mathrm{R}^{2}$ & $\underline{0,272}$ & & & & & & & \\
\hline Adjusted $\mathrm{R}^{2}$ & 0,270 & & & & & & & \\
\hline Estimated Standard Error & 9,98265 & & & & & & & \\
\hline$\overline{F_{(1-401)}}$ & 149,847 & & z & & & & & \\
\hline Sig. & $0,000^{* *}$ & & & & & & & \\
\hline Durbin-Watson & 1,897 & & & & & & & \\
\hline
\end{tabular}

As can be inferred from the regression tables indicating the effects of teammember exchange on contextual performance, the regression model 2 created were significant. $\left(\mathrm{R}^{2}=0,272 ; \mathrm{F}_{(1-401)}=149,847 ; \mathrm{p}<0,01\right)$. According to pair-wise (linear) regression analysis, it was observed that team-member exchange levels of the participants positively influenced their contextual performance $(\beta=0,522 ; p<0,01)$.

VIF (Variance Inflation Factors) value was calculated as 3,294 in the regression model. The highest value in the literature is accepted to be 10 (Gujarati and Porter, 2009). This value is well below 10 value. Again, the tolerance value is 0.281 ; is much higher than the lowest value $(0,100)$ (Hair et al., 1992). It means that there is not a multicollinearity problem in the regression model. In addition, it is seen that the CI 
(condition index) value is 11,137 . This is much lower than the top value of 30 . Also, the Durbin-Watson coefficient is 1,897. So it is below the value of 2 that should not exceed (Gujarati and Porter, 2009). Therefore, there is no autocorrelation problem in the regression model.

Team-member exchange was able to explain $27 \%$ of the variation in contextual performance (adjusted $R^{2}=0,270$ ). Then, based on these results, Hypothesis 4 was accepted.

\section{DISCUSSION}

Teamwork has to gain ever-increasing significance in businesses. Therefore, several studies have been conducted about mediating or moderator role of teammember exchange which was emerged as a concept all by itself to make teamwork more efficient. Then, the relationships between team-member exchange and employee performance have been searched, and studies on this issue gained a great significance.

Correlation analysis was performed to determine the relations of team-member exchange with the task and contextual performance of the employees. There was a highly weak significant positive correlation between team-member exchange and task performance of the employees $(r=0,502, p<0,01)$. A relatively strong significant positive correlation was observed between team-member exchange and contextual performance of the employees $(r=0,522, p<0,01)$. Liu, Keller and Shih (2011) reported slightly strong significant positive correlation between team-member exchange and team performance $(r=0,51, p<0,01)$ (Liu, Keller and Shih, 2011: 280). Tse and Lawrence (2010) also reported slightly strong significant positive correlation between team-member exchange and team performance $(r=0,55, p<0,01)$. Present findings comply with the findings of those two studies (Tse and Lawrence, 2010: 18). Seers (1989) indicated a weak significant positive correlation between team-member exchange and team performance $(r=0,24, \mathrm{p}<0,05)$ (Seers, 1989: 127-128). Kamdar and Van Dyne (2007) reported relatively weak significant positive correlations between team-member exchange and task performance $(\mathrm{r}=0,16, \mathrm{p}<0,01)$ (Kamdar and Van Dyne, 2007: 1292). Liden, Wayne and Sparrowe (2000) indicated relatively weak 
significant positive correlations between team-member exchange and work performance $(r=0,19, \mathrm{p}<0,01)$ (Liden, Wayne and Sparrowe, 2000: 412-414). Liu, Loi and Lam (2011) reported relative quite weak significant positive correlations between team-member exchange and task performance $(\mathrm{r}=0,16, \mathrm{p}<0,05)$, but reported insignificant correlations between team-member exchange and contextual performance (Liu, Loi and Lam, 2011: 3194). Pollack et al (2016) reported relative quite weak significant positive correlations between team-member exchange and number of guidance given $(r=0,15, \mathrm{p}<0,01)$ and between team-member exchange and number of guidance taken $(r=0,14, p<0,01)$ (Pollack et al., 2016: 31). The correlations between team-member exchange and performance in those studies were lower than the present values.

Pair-wise (linear) regression analysis carried out to determine the effects of team-member exchange on task, and contextual performance of the employees revealed that team-member exchange positively influenced task performance $(\beta=$ 0,$502 ; p<0,01$ ). Team-member exchange explained $25 \%$ of the variation (adjusted $\mathrm{R}^{2}=$ $0,250)$ in task performance. Team-member exchange also positively influenced contextual performance $(\beta=0,522 ; \mathrm{p}<0,01)$ and explained $27 \%$ of the variation (adjusted $\mathrm{R}^{2}=0,270$ ) in contextual performance. According to Seers (1989), when it was taken as an independent variable, team-member exchange positively influenced performance and explained $5 \%$ of the variation (adjusted $\mathrm{R}^{2}=0,05$ ) in performance (Seers, 1989: 131). In the present study, effects of team-member exchange on performance were greater. Suskind, Behfar and Borcgrevink (2006) were not able to identify positive effects of team-member exchange on effort-share performance $(\beta=$ $0,04, p=0,77)$, but reported positive effects of team-member exchange on informationshare performance $(\beta=0,37, p=0,05)$. Team-member exchange explained $12 \%$ of the variation in information-share performance (Suskind, Behfar and Borcgrevink, 2006: 129-131). Present values were greater than the values of those previous studies. Seers et al. (2001) reported that team-member exchange contributions positively influenced both the horizontal and vertical activities of the executives $(\beta=0,245, p<0,05)$, but they were not able to prove positive impacts of team-member exchange receipts on horizontal and vertical activities of the executives (Seers et al., 2001: 12). 


\section{CONCLUSION AND RECOMMENDATIONS}

In the present study, the positive effects of team-member exchange on employee performance were tried to be proved, and such effects were identified. The primary target was to increase researcher interest in team-member exchange studies, to allow a better comprehension of team-member exchange by organization executives and let them focus on activities to improve team-member exchange levels. It was concluded based on present findings and earlier literature that team-member exchange had positive effects on task and contextual performance of the employees.

Based on the 5-point Likert scale, the average was identified as 3,64 for teammember exchange, 4,00 for task performance and 3,93 for contextual performance. The present research sample was composed of employees of manufacturing firms. Works are performed in departments in these firms, and the structure is entirely available for team works. Thus, team-member exchanges levels were relatively high in this study. Competitive conditions, prominent profitability and customer-oriented business style of these firms also positively influenced task and contextual performance of the employees. Self-criticisms of the employees might have also influenced their performance scores.

According to correlation analysis results, there was a highly weak significant positive correlation between team-member exchange and task performance of the employees $(r=0,502, p<0,01)$. A relatively strong significant positive correlation was observed between team-member exchange and contextual performance of the employees $(r=0,522, p<0,01)$. In correlation analysis, variables are subjected to analysis either as a precursor or outcome. Therefore, moving only from the results of correlations analysis, it can be stated that there were positive correlations between team-member exchange and task-contextual performance of the employees, in other words, one increases with increasing values of the other.

Regression analysis carried out to determine the effects of team-member exchange on task, and contextual performance of the employees revealed that teammember exchange positively influenced task performance $(\beta=0,502 ; p<0,01)$ and 
explained $25 \%$ of the variation (adjusted $R^{2}=0,250$ ) in task performance. Teammember exchange also positively influenced contextual performance $(\beta=0,522 ; p<$ 0,01 ) and explained $27 \%$ of the variation (adjusted $R^{2}=0,270$ ) in contextual performance. As can be inferred from these findings, it was concluded that teammember exchange was a significant predictor for the task and contextual performance of the employees.

Stronger relationships between team-member exchange and contextual performance than between team-member exchange and task performance can result from the fact that contextual performance included activities other than primary components of the job and realized with the initiative of the employee, thus more influenced by the interpersonal relations and perception of these relations. However, task performance was mostly composed of primary components of the job, in other words, of the compulsory things to be done, thus influenced less from interpersonal relations and perception of these relations.

More significant interpersonal relations and team-member exchange levels positively influence employee performance. With an efficient team-member exchange, both the contributions to the other members and the receipts from the other members are improved, cooperation is strengthened. Thus employees feel more comfortable and confident. Besides these benefits, higher team-member exchange levels also allow team members to trust each other more and be of sure that they will not suffer from the other team members.

Based on present findings, the following recommendations were made to the organization executive, especially to human resources managers: While forming the teams, appropriate arrangements should be made based on the social needs of the employees. Such a case then will positively influence employee performance (Tutar and Altınöz, 2010: 200). Social activities should be organized in organizations to improve interpersonal relations and concordance. It is quite significant that task definitions should include behaviours for charitableness and cooperation. In this way, contributions will be provided to the performance of employees (Alparslan and Can, 2015: 27). In training programs, the team works, unity and concordance should 
frequently be focused on. For the jobs requiring significant teamwork, competence for teamwork, unity, concordance and cooperation should be included in selection and assessment criteria. When the problems and deficiencies were observed in teammember exchange, relevant rotations should be applied. Emphasis should be placed on meeting organization since it is a dimension of team-member exchange. That is to say, relevant preparations should be made, participants should be informed in time, opinions of all should be taken, chairman, reporter and the like staff should be selected, decisions made in this meeting should be followed, and all the other relevant activities should be performed.

Recommendations to researchers are as follows: A questionnaire was applied to manufacturing firms in this study. Similar studies can be applied to the service sector, finance sector, retail sector and similar businesses in which employees are in more significant interactions with the customers, costumer-oriented business is shared, and interpersonal relations and interactions are more significant. Such studies can easily be applied to virtual teams quite common in these businesses. It was observed in previous literature about the relationships between team-member exchange and performance that correlation analysis and interrelations were more focused on. In future studies, team-member exchange can be more focused on as a performance predictor variable. Team-member exchange is a concept with everincreasing significance in businesses. There are several studies in literature taking team-member exchange as a precursor. In further studies, effects of the precursors of team-member exchange such as personality, organizational commitment, political behaviour, tend of rumour, tend of release, organizational democracy, executive performance, organizational cynism, psychological capital, motivation, etc. on teammember exchange can be investigated. Predictor effects of task and contextual performance, which are the outcomes of team-member exchange, on the team-member exchange can also be investigated in further studies.

Finally, it was recommended that team-member exchange should be investigated not only in the science of management but also in educational sciences (quality of education, grade-point average, adoption of the course or instructor), health 
sciences (treatment duration, interactions with the patients), sports sciences (team performance, youth setup), sociology (neighbour relations, relative relations) and in some other sciences/disciplines. 


\section{REFERENCES}

Akdoğan, A., A., Cingöz, A. and Selen Oflazer Mirap, S., O. (2009) Lider-Üye Etkileşiminin/Değişiminin Yenilikçi İş Performansı, Görev Performansı ve Bağlamsal Performans Üzerindeki Etkisinin Belirlenmesi 17. Ulusal Yönetim ve Organizasyon Kongresi Bildiriler Kitabı" Eskişehir, 380-381.

Aktaş, H. ve Şimşek, E. (2014). Örgütsel Sessizlik ile Algilanan Bireysel Performans, Örgüt Kültürü ve Demografik Değişkenler Arasindaki Etkileşim. Akdeniz Üniversitesi İktisadi ve İdari Bilimler Fakültesi Dergisi, 14(28), 24-52.

Alge, B.J., Wiethoff, C. and Klein, H.J. (2003). When Does the Medium Matter? Knowledge-Building Experiences and Opportunities in Decision-Making Teams, Organizational Behavior and Human Decision Processes, 91, 2003, 26-37.

Allison, B. B., (2016) An Examination of Leader-Member Exchange and Team Effectiveness, Clemson University The Graduate School of Industrial and Organizational Psychology, Clemson, (The Degree of Doctor of Philosophy).

Alparslan, A. M. and Can, A. (2015). The Antecedents of Extra-Role Organizational Behaviors: A Qualitative Research on Soldier, Journal of Business Research Turk, 7 (1), 26-42.

Banks, G.C., J. H. Batchelor, J. H., Seers, A., O'Boyle Jr., E. H., Pollack, J. M. and Gover, K. (2014). What Does Team-Member Exchange Bring to the Party? A Meta-Analytic Review of Team and Leader Social Exchange, Journal of Organizational Behaviour, Vol. 35 Issue 2, February 2014, 273-295.

Borman, W. C. and Motowidlo, S.J. (1997) Task Performance and Contextual Performance: The Meaning for Personnel Selection Research, Human Performance, 10 (2), 99-109.

Cogliser, C. C., Gardner, W., Trank, C. Q., Gavin, M., Halbesleben, J., \& Seers, A. (2013). Not all group exchange structures are created equal: Effects of forms and levels of exchange on work outcomes in virtual teams. Journal of Leadership \& Organizational Studies, 20(2), 242-251.

Fluid Surveys University, [Online] available at http://fluidsurveys.com/university/survey-samplesize-calculator/ accessed on July 2017.

Gujarati, D. N., and Porter, D. (2009) Basic Econometrics. (5th ed.). New York: McGraw-Hill Irwin.

Hair, J., Anderson, R., Tatham, R. and Black, W. (1992) Multivariate Data Analysis, second ed. Macmillan Publishing Company, New York. 
Han, T., Chiang, H. and Chiang, C. (2013) The Investigation of the Relation between Personorganization Fit, Person-job Fit, Psychological Ownership, and Contextual Performance: A Longitudinal Approach Proceedings of International Conference on Information and Social Science (ISS) $\mathcal{E}$ International Symposium on Marketing, Logistics, and Business (MLB) Nagoya, 274-299.

Ilgen, D. R., J.R. Hollenbeck, M. Johnson and Dustin Jundt. (2005). Teams in Organizarions: From InputProcess-Output Models to IMOI Models, Annu. Rev. Psychol., 56, 517-543.

Kamdar, D. and Van Dyne, L. (2007). The Joint Effects of Personality and Workplace Social Exchange Relationships in Predicting Task Performance and Citizenship Performance, Journal of Applied Psychology, Vol. 92, Number 5, 1286-1298.

Kayseri Valiliği Çevre ve Şehircilik İl Müdürlüğü Çed İzin ve Denetim Şube Müdürlüğü, Kayseri İli 2015 Y1lı Çevre ve Durum Raporu, (Kayseri Province 2015 Yearly Environment and Situation Report), Kayseri 2016.

Kidney, R. A., (2013) The Relationship Between Attachment Styles and Employee Creativity: Evidence from the Engineering Industry, Dublin City University Business School, Dublin, (The Degree of Doctor of Philosophy).

Klein, K. J. and Kozlowski, S. W. J. (2000). Multilevel Theory, Research, and Methods in Organizations Foundations, Extensions and New Directions, Jossey-Bass A Wiley Company, First Edition, San Francisco.

Kozlowski, S. W. J. and Bell, B. S. Bell (2001). Work Groups and Teams in Organizations, Cornell University ILR School Articles and Chapters ILR Collection, 1-82. [Online] available at http:/ / digitalcommons.ilr.cornell.edu/articles accessed on February 2017.

Lau, R. S. (2009) A Group-Level Examination of the Impact of Leader-Member Exchange and Justice Climates on Team-Member Exchange, The Annual Meeting of the Academy of International Business Southeast Asia Regional Conference, Hong Kong. [Online] available at http://www.ouhk.edu.hk/

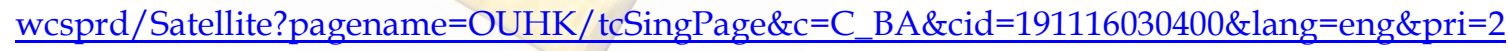
accessed on March 2017.

Liden, R. C., Wayne, S. J. and Sparrowe, R. T. (2000). An Examination of the Mediating Role of Psychological Emprowerment on the Relations Between the Job, Interpersonal Relationships and Word Outcomes, Journal of Applied Psychology, Vol. 85 Number 3, 407-416.e

Liu,Y., Keller, R. T. and Shih, H. (2011). The Impact of Team-Member Exchange, Differentiation, Team Commitment, and Knowledge Sharing on R \& D Project Team Performance, Blackwell Publishing Ltd. $R$ $\mathcal{E}$ D Management, 41, 3, 274-287. 
Liu, Y., Loi, R. and Lam, L. W. (2011). Linking Organizational Identification and Employee Performance in Teams: the Moderating Role of Team-Member Exchange, The International Journal of Human Resource Management, Vol. 22, Number 15, 3187-3201.

Motowidlo, S. J., Borman, W. C., and Schmit, M. J. (1997). A Theory of Individual Differences in Task and Contextual Performance, Human Performance, 10, 2, 71-83. Motowidlo, Stephan J. and Van Scotter, J. R. (1994). Evidence that Task Performance Should be Distinguished from Contextual Performance, Journal of Applied Psychology, Vol. 79, 475-480.

Motowidlo, S. J. (2003). Job Performance, 39-53, in Handbook of Psychology Volume 12 Industrial and Organizational Psychology, Eds. Borman, Walter C., Daniel R. Ilgen, Richard J. Klimoski, John Wiley and Sons, New Jersey.

Murphy, K., R. and Shiarella, A. H. (1997) Implication of the Multidimensional Nature of Job Performance for the Validity of Selection Tests: Multivariate Frameworks for Studying Test Validity", Personnel Psychology, 50, 832.

Nakip, M. (2013). Pazarlamada Araştırma Teknikleri, (Research Techniques in Marketing),Seçkin Yayıncılık, Üçüncü Baskı, Ankara.

Özkan, Ü. A. and Börekçi, D. Y. (2013) Farklı Lider-Üye ve Ekip-Üye Kombinasyonlarının Göreceli Yoksunluk ve Pozitif Örgütsel Davranış Bağlamında İş Sonuçlarına Etkisi, 1. Örgütsel Davranış Kongresi Bildiriler El Kitabı, Sakarya 2013, 110-116.

Pollack, J. M. and Rutherford, M. W. (2008). Social Ties and Team-Member Exchange as Antecedents to Firm Performance, Frontiers of Entrepreneurship Research, Vol. 28, Issue 7, Temmuz, 1.

Pollack, J. M., Rutherford, M. W., Seers, A., Anthony, E. C., and Hanson, S. (2016). Exploring Entrepreneurs' Social Network Ties: Quantity Versus Quality, Journal of Business Venturing Insights, Vol. 6, Aralık.

Polatcl, S. (2014) Psikolojik Sermayenin Görev ve Bağlamsal Performans Üzerindeki Etkileri: Polis Teşkilatında Bir Araştırma, Ege Akademik Bakış, Cilt 14, Sayı, 1 Ocak, 115-124.

Rudman, R. (2003). Performance Planning and Review Making Employee Appraisals Work, Allen \& Unwin, Second Edition, Sydney.

Schmitt, N., Cortina, J. M., , Ingerick M. J. and Wiechmann D. (2003). Personnel Selection and Employee Performance, 77-105, in Handbook of Psychology Volume 12 Industrial and Organizational Psychology, Eds. Borman, Walter C., Daniel R. Ilgen, Richard J. Klimoski, John Wiley and Sons, New Jersey. 
Seers A., (1989). Team-Member Exchange Quality: A New Construct for Role-Making Research, Organizational Behavior and Human Decision Processes, 43, 118-135.

Seers, A., Ford, L. R., Wilkerson, J. M., and Moormann, T. E. (2001). The Generation of Influence: Effects of Leader-Member Exchange and Team-Member Exchange Paper Presented at The Annual Meetings of the Southern Management Association, April, 1-22.

Sonnentag, S and Frese, M. (2002). Performance Concepts and Performance Theory, 4-25, in Psychological Management of Individual Performance, Ed. Sonnentag, Sabine, John Wiley and Sons West Sussex.

Shentu, Teng, Halim, V., Kusna, J. K. and Kusna, J. K. (2013). Different Perception of Working Relationship in Intercultural Working Team, International Conference on Psychology in Healt Educational, Social, and Organization Setting Proceedings Book, Surabaya November, 766-774.

Suskind, A. M., Behfar K. and Borcgrevink, C. P. (2006). An Explaration of the Relationship Between Communication Network Structures Team-Member Exchange Quality and Teamwork, 119-136, in Sharing Network Leadership, Eds. Graen George B. And Joni A. Graen, Information Age Publishing, Connecticut.

Şahin, F., and Gürbüz, S. (2012) Kültürel Zekâ ve Öz-yeterliliğin Görev Performansı ve Örgütsel Vatandaşlık Davranışı Üzerinde Etkisi: Çokuluslu Örgüt Üzerinde Bir Uygulama. ISGUC The Journal of Industrial Relations and Human Resources, 14(2), 123-140.

Timur, H. ve Kılıç, M. (2005). İş Değerlendirmesinde Puanlama Yöntemi (İki Örnek Uygulama), (Job Evaluation Scoring Method (Two Sample Application)), Hacettepe Üniversitesi Yayınları, Ankara.

Tse, H. H. M. and Dasborough, M. T. (2008). A Study of Exchange and Emotions in Team Member Relationships, Group \& Organization Management, Vol. 33, Number 2, April, 194-215.

Tse, H. H. M. and Lawrence, S.A. (2010). Leader-Member Exchange Differentiation and Team Performance: The Role of Group Affective Climate Team-Member Exchange, Conference: 27th International Congress of Applied Psychology, Melbourne, 1-22. [Online] available at http:// www98.griffith.edu.au/dspace/bitstream/handle/10072/53522/83593_1.pdf?sequence=1 accessed on January 2016.

Tuna, B. (2014) The Influence of Person-Orgaization Fit on Contextual Performance and Its Impact on Organizational Effectiveness: The Moderating Role Of Organizational Climate, Yeditepe University Graduate Institute of Social Sciences, İstanbul, (The Degree of Doctor of Philosophy).

Tutar, H. ve Altınöz, M. (2010). Örgütsel İklimin İşgören Performansı Üzerine Etkisi: Ostim İmalât İşletmeleri Çalışanları Üzerine Bir Araştırma, (The Effect of Organizational Climate on Employee 
Performance: A Study on the Employees of Ostim Manufacturing Enterprises), Ankara Üniversitesi SBF Dergisi, $65,2,195-218$.

Ünlü O. ve Yürür, S. (2011) Duygusal Emek, Duygusal Tükenme ve Görev/Bağlamsal Performans İlişkisi: Yalova'da Hizmet Sektörü Çalışanları İle Bir Araştırma, Erciyes Üniversitesi İktisadi ve İdari Bilimler Fakültesi Dergisi, Cilt: 184 Sayı: 37, 183-207.

Van Scotter, J. R. and Motowidlo, S. J. (1996). Interpersonal Facilitation and Job Dedication as Separate Facets of Contextual Performance, Journal of Applied Psychology, Vol 81. Number 5, 525-531.

Williams, L. J. and Anderson, S. E. (1991). Job Satisfaction and Organizational Commitment as Predictors of Organizational Citizenship and In-Role Behaviours, Journal of Management, Vol. 7, Number 3, 601-617.

Witt, L.A., Hochwarter, W. A., Thomas F. Hilton, T. F. and Hillman, C. M. (1999) Team-Member Exchange and Commitment to a Matrix Team, Journal of Social Behaviour and Personality, Vol. 14 No. 1, 63-74. 